\title{
The Effect of Commercial Probiotics on the Phytoplankton Diversity Associated with Biofloc
}

\author{
Fitri Anisha Kurniawati ${ }^{1}$, Endang Dewi Masithah ${ }^{1^{*}}$, and Boedi Setya Rahardja ${ }^{2}$ \\ ${ }^{1}$ Department of Marine Science, Faculty of Fisheries and Marine, Universitas Airlangga, Surabaya-60115, Indonesia \\ ${ }^{2}$ Department of Fish Health Management and Aquaculture, Faculty of Fisheries and Marine, Universitas Airlangga, Surabaya-60115, Indonesia \\ *Corresponding author’s Email: endang-d-m@fpk.unair.ac.id; (DORCiD: 0000-0003-4082-8147
}

\begin{abstract}
The intensive aquaculture industry faces two main problems, first, the decrease in the water quality caused by high concentrations of metabolites, and second, the use of low natural food in aquaculture activities with high water exchange intensity. For this reason, efforts are needed to develop biofloc to maximize the contribution of natural food which can increase aquaculture production. The present study aimed to analyze the effect of commercial probiotics on the differences in the phytoplankton diversity associated with biofloc. The fish were divided into three treatment groups. Treatment A involved biofloc formation without using probiotics, treatment B contained biofloc formation using commercial probiotics (Bacillus spp., lactic acid, Lactobacillus spp., Saccharomyces spp. 50/50 feed), and treatment $\mathrm{C}$ entailed biofloc formation using commercial probiotics (containing a native microbial consortium, 50/50 feed). The treatment groups were repeated six times so that there were 18 experimental units. The research was conducted from March to April 2015. The results indicated that the administration of probiotics with different types led to insignificant differences among the treatment groups. The highest diversity index value occurred in treatment $\mathrm{C}$ on day 34 of the experiment that was equal to 0.49 . On the other hand, the highest value of the dominance index $(\mathrm{C}=0.99)$ occurred in treatments $\mathrm{A}$ and $\mathrm{B}$ on day 21 . It can be concluded that the addition of probiotics with different biofloc could result in insignificant phytoplankton diversity. Furthermore, the Nitrogen/Phosphorus (N/P) ratio as a limiting factor for phytoplankton growth indicated different results in each treatment.
\end{abstract}

Keywords: Biofloc, Phytoplankton, Probiotic differences

\section{INTRODUCTION}

Nowadays, there has been a rapid development in aquaculture activities indicated by an increase in fishery production, and a decline in capture fisheries production. Therefore, aquaculture is suggested as an alternative that can be relied upon and developed (Mukti et al., 2003). Today, many individuals rely on fisheries and aquaculture for food needs and as a source of income.

In such a situation, aquaculture meets several challenges, especially those related to natural resources, such as water and land. The application of intensive cultivation patterns has become a possible choice in increasing aquaculture production. Although several efficient measures have been taken to develop aquaculture, especially intensive systems, there is still a need to examine such constraints. Amongst, these are aquaculture waste discharges, the use of fish meal as raw material for artificial feed, and the spread of diseases. Intensive aquaculture systems are carried out efficiently to produce solid biomass in fish or shrimp. However, the intensive aquaculture industry faces two main problems, the first is the decline in water quality caused by high concentrations of metabolites, and second, the utilization of low natural feed in aquaculture activities with high water exchange intensity (Wyk and Avnimelech, 2007).

Promoting a zero-exchange-water system can be an efficient step to reduce the negative impact, so as to reduce the risk of pollution by aquaculture wastes (Crab et al., 2009). As reported, the process of decomposition of organic matter by aerobic bacteria will cause a decrease in oxygen content in water, and the accumulation of organic matter in the pond will increase the population of bacteria in pond water (Avnimelech et al., 2008). As a result, there is a need to change toxic nitrogen compounds (ammonia) to nitrate by applying biofloc technology (Avnimelech, 1999). Biofloc technology maximizes the contribution of natural food and increases aquaculture production (Ogello et al., 2014). Biofloc production depends on the supply of organic substrates, either external sources (feed supply, algal activity) or with residual excretions by fish. The process of biofloc formation is also influenced by environmental conditions, such as temperature and salinity (Wyk and Avnimelech, 2007). With this in mind, the current study investigated the effect of two commercial probiotics on the diversity of phytoplankton associated with biofloc. The study was conducted by forming 
biofloc using two different commercial probiotics, namely commercial probiotics $\mathrm{B}$ and commercial probiotics $\mathrm{C}$, then floc sampling was taken to observe the diversity of phytoplankton.

\section{MATERIALS AND METHODS}

\section{Ethical approval}

All experimental protocols and procedures were approved by the Institutional Animal Care of Indonesia. The current experimental method was conducted using an observation under artificial conditions, in which conditions were created and regulated by researchers. To obtain accurate results, the study was conducted at the Educational Laboratory of the Faculty of Fisheries and Maritime Affairs, Universitas Airlangga, Surabaya in Indonesia. The examination of the Carbon/Nitrogen $(\mathrm{C} / \mathrm{N})$ and Nitrogen/Phosphorus (N/P) ratio of the water was conducted at the Environmental Quality Laboratory of the Faculty of Civil Engineering and Planning, Sepuluh November Institute of Technology Surabaya in Indonesia. The research was conducted from March to April 2015.

The applied instruments in the current study included aquarium measuring $40 \times 20 \times 35 \mathrm{~cm} 3$, cone glass tube (Imhoff cone), aerator, aeration stone, aeration hose, analytical balance, pipette, $\mathrm{pH}$ meter, thermometer, Dissolved oxygen kit, ammonia kit, hemocytometer, cover glass, and microscope. In addition, the utilized materials were two kinds of probiotics (probiotics B and C) produced by containing Bacillus spp., lactic acid, Lactobacillus spp., Saccharomyces spp., molasses, fish pellets, bran, chlorine, and dolomite.

The experimental design used by researchers was a completely randomized design. In this design, there was only one source of diversity, namely treatment in addition to random effects, so the results of differences among treatments were only due to the effects of treatment and random effects. For this reason, this experiment consisted of three treatments, namely treatments A, B, and C. Treatment A contained biofloc formation without using probiotics, the treatment B involved biofloc formation using commercial probiotics (Bacillus spp., lactic acid, Lactobacillus spp., Saccharomyces spp. 50/50 feed), and treatment C entailed biofloc formation using commercial probiotics (containing a native microbial consortia, 50/50 feed ), which were repeated six times leading to 18 experimental units, namely: A1, A2, A3, A4, A5, A6, B1, B2, B3, B4, B5, B6, C1, C2, C3, C4, C5, and C6. Formulation of probiotics/feed was according to Arias-Moscoso et al. (2018).

The $\mathrm{pH}$ value describes the acidity and alkalinity intensity of water samples indicated by the presence of hydrogen ions. Most aquatic biotas are sensitive to changes in $\mathrm{pH}$, and prefer a $\mathrm{pH}$ value of around 7-8.5. The $\mathrm{pH}$ value also greatly influences the biochemical processes of the water samples, such as nitrification. At $\mathrm{pH}<4$, most aquatic plants die (Effendi, 2003). On the other hand, it is known that water with a pH of 6-9 is highly fertile, and is considered productive since the $\mathrm{pH}$ range of water can encourage the process of dismantling organic matter into minerals that can be assimilated by phytoplankton (Odum, 1953). For this reason, $\mathrm{pH}$ measurements in this study were carried out at 06.00 in the morning and 17.00 in the afternoon. The weekly dynamics of $\mathrm{pH}$ were measured along with ammonia at the beginning of the study.

\section{RESULTS AND DISCUSSION}

\section{Diversity index and dominance index of phytoplankton types}

The stability of the community of water samples can be described from the value of diversity index $\left(\mathrm{H}^{\prime}\right)$ and dominance index (C). Data on the diversity index and dominance index of phytoplankton were observed for 34 days of the research (Table 1).

As can be seen, the diversity index values $\left(\mathrm{H}^{\prime}\right)$ on the seventh day of the observation ranged $0.16-0.33,0.04-0.08$ on day $14,0.03-0.05$ on day $21,0.04-0.29$ on day 28 , and $0.13-0.49$ on day 34 . The index of dominance ranged $0.90-0.93$, $0.96-0.98,0.98-0.99,0.89-0.98$, and $0.75-0.95$ on days $7,14,21,28$, and 34 of the observation, respectively.

Regarding the dynamics of the diversity index, treatment $\mathrm{A}$ had the highest diversity index value on day 7 , and it decreased on days 14 and 21. Following that, it increased again on days 28 and 34. Treatment B showed a diversity index value of 0.16 on day 7 , an increase on day 14 , and a decrease on day 21 . However, it continued to increase during days 28-34 of the study. On the other hand, treatment $\mathrm{C}$ indicated a diversity index value of 0.33 on day 7 , a decrease on day 14 , an increase on day 21, and a decrease again on day 28. The highest diversity index value of 0.49 occurred on day 34. The highest diversity index fluctuation occurred in treatment $\mathrm{C}$.

The results of dynamics of dominance in each treatment indicated that treatment A led to a dominance index value of 0.91 on day 7, and it continued to increase during 14-21 days of the study. However, a decrease was observed from day 28 to day 34. Treatment B also showed a dominance index value of 0.93 on day 7 , and it continued to increase during 14-21 days of the experiment, but there was a significant decrease from day 28 to 34 . In addition, treatment $\mathrm{C}$ contributed to the dominance index value of 0.90 on day 7 , and an increase on day 14 reaching 0.98 . This value was stable until day 28 , and it decreased on day 34 . The highest dominance index fluctuation occurred in treatments A and B. 
Table 1. Diversity index and phytoplankton dominance index of treatment groups

\begin{tabular}{|c|c|c|c|c|c|c|c|c|c|c|}
\hline \multirow{2}{*}{ Treatment } & \multicolumn{2}{|c|}{ Day 7} & \multicolumn{2}{|c|}{ Day 14} & \multicolumn{2}{|c|}{ Day 21} & \multicolumn{2}{|c|}{ Day 28} & \multicolumn{2}{|c|}{ Day 34} \\
\hline & $\mathrm{H}^{\prime}$ & $\mathrm{C}$ & $\mathrm{H}^{\prime}$ & $\mathrm{C}$ & $\mathrm{H}^{\prime}$ & $\mathrm{C}$ & $\mathrm{H}^{\prime}$ & $\mathrm{C}$ & $\mathrm{H}^{\prime}$ & $\mathrm{C}$ \\
\hline$A^{1}$ & 0.22 & 0.91 & 0.08 & 0.97 & 0.04 & 0.99 & 0.06 & 0.98 & 0.13 & 0.95 \\
\hline$B^{2}$ & 0.16 & 0.93 & 0.08 & 0.96 & 0.03 & 0.99 & 0.29 & 0.89 & 0.42 & 0.79 \\
\hline$C^{3}$ & 0.33 & 0.90 & 0.04 & 0.98 & 0.05 & 0.98 & 0.04 & 0.98 & 0.49 & $0 ’ 75$ \\
\hline
\end{tabular}

H': diversity index, C: Phytoplankton dominance index, $\mathrm{A}^{1}$ : Biofloc formation without using probiotics, $\mathrm{B}^{2}$ : Biofloc formation using commercial probiotics (Bacillus spp., lactic acid, Lactobacillus spp., Saccharomyces spp. 50/50 feed), C $\mathrm{C}^{3}$ : Biofloc formation using commercial probiotics (containing a native microbial consortium, 50/50 feed)

\section{Types of phytoplankton that grow}

Weekly observations of the phytoplankton types associated with biofloc in all treatments obtained 20 species, namely Pediastrum spp., Microcystis spp., Anabaena spp., Asterionella spp., Diatom Vulgare, Euglena spp., Chaetoceros spp., Chroococcus spp., Dactylococcopsis spp., Gyrosigma spp., Cyclotella spp., Eudorina spp., Bacillariophyta spp., Surirella spp., Nitzschia spp., Melosira spp., Gomphonema spp., Dictyosphaerium spp., and Osillillophia spp. The type of phytoplankton found during the observation was dominated by Microcystis spp.

\section{Water quality}

\section{Temperature}

Surface water temperature is under the influence of meteorological conditions, such as rainfall, evaporation, air humidity, air temperature, wind speed, and intensity of solar radiation (Nontji, 2007). In the current study, temperature measurements were carried out every day for a month. As observed in these measurements, the temperature was within the range of 27 to $28.5^{\circ} \mathrm{C}$.

\section{Ammonia}

Ammonia measurements were carried out at the beginning and the end of the study at the Laboratory of Environmental Quality, Faculty of Civil Engineering and Planning, Sepuluh November Institute of Technology (Indonesian). The ammonia value at the beginning of the study ranged from 531.51 to $921.15 \mathrm{mg} / \mathrm{l}$. Ammonia value at the end of the study was within the range of 1345.08 to $1926.13 \mathrm{mg} / 1$.

\section{Dissolved oxygen}

Dissolved oxygen (DO) measurements were carried out once a week together with temperature and ammonia measurements, so there were four DO measurements. The average DO values of treatment A were 5.3, 4.7, 4, and 4 mg/l in the first, second, third, and fourth weeks, respectively. Regarding treatment B, these values were reported as 4.3, 4.7, $4.3,4.3 \mathrm{mg} / \mathrm{l}$ in the first, second, third, and fourth weeks, respectively. Considering treatment $\mathrm{C}$, the estimated values were $4.7,5,4.3,4.3 \mathrm{mg} / \mathrm{l}$ for the first, second, third, and fourth weeks, respectively.

\section{PH value}

The $\mathrm{pH}$ value in the first week was quite high and ranged 5.8-6.4. However, in the second week, the $\mathrm{pH}$ value began to fall to reach the lowest value of 3.8. In the third week, the $\mathrm{pH}$ value tended to increase. In the fourth week, the $\mathrm{pH}$ values in treatments $\mathrm{A}, \mathrm{B}$, and $\mathrm{C}$ tended to be the same ranging from 4 to 6 . The results of average water quality measurements during the study can be seen in Table 2 .

Table 2. Range of water quality values during the study

\begin{tabular}{lc}
\hline Parameters & Range \\
\hline Temperature & $27-28.5^{\circ} \mathrm{C}$ \\
Ammonia & $531.51-1.926 .13 \mathrm{mg} / \mathrm{l}$ \\
Dissolved oxygen & $4-6 \mathrm{mg} / 1$ \\
$\mathrm{pH}$ & $3.8-7.6$ \\
\hline
\end{tabular}

\section{Value of nitrogen/phosphorus ratio}

The results of the measurement of the Nitrogen/Phosphorus (N/P) ratio at the beginning of the study showed that treatment B had the highest yield of 4.4, followed by treatment A (3) and treatment $\mathrm{C}(2.1)$. The highest $\mathrm{N}$ content at the start of the study was obtained from treatment B $(921 \mathrm{ppm})$, followed by treatment A (608.1 ppm), and finally by treatment $\mathrm{C}(531.5 \mathrm{ppm})$. The highest $\mathrm{P}$ content was obtained at treatment $\mathrm{C}(255.5 \mathrm{ppm})$, followed by treatment $\mathrm{B}$ (210.0 ppm), and finally treatment A (201.3 ppm).

The results of the N/P measurement ratio at the end of the study showed that treatment $\mathrm{A}$ gave the highest N/P ratio (5.68), followed by treatment $\mathrm{B}$ (4.78), and finally treatment $\mathrm{C}$ (4.36). The highest $\mathrm{N}$ content was obtained from treatment A (1692.6 ppm), followed by treatment B (1668.6 ppm), and the lowest was treatment C (1631.04 ppm). On 
the other hand, the highest P content was seen in treatment B (451.8 ppm), followed by treatment $\mathrm{C}$ ( $372.6 \mathrm{ppm})$, and the lowest belonged to treatment A (324.6 ppm). The comparison of the beginning and end of the study indicated an increase in the N/P ratio values for all treatments. Furthermore, the N content and P content increased in all treatments.

Considering the obtained results, it can be seen that phytoplankton are planktonic plants free to float off and drift in the sea, and able to photosynthesize. Phytoplankton has chlorophyll to photosynthesize and produce organic compounds, such as carbohydrates and oxygen. On the other hand, the results of observations indicated that the value of the plankton diversity index ranged from 0.03 to 0.49 . Based on this range, the diversity of phytoplankton in general for all observations every week belonged to the classification with low diversity $\left(\mathrm{H}^{\prime}<2.036\right.$, Shannon-Wiener diversity index standard). This parameter characterized the richness of the species and balance in a community. Recently, there has been a decline which has made the diversity of phytoplankton low. Ecosystems with low diversity show unstable conditions, and are vulnerable to the influence of external pressures, compared to ecosystems that have a high diversity (Nybakken and Eidman, 1992).

Based on the observations, the dominance index value in all treatments ranged from 0.75 to 0.99 , meaning that water samples in the treatment had a high dominance value. Phytoplankton type was dominated by the genus Microcystis spp., which was found in all observed samples. The reason for this could be the warm tropical climate of Indonesia during the year. This can be a place for the growth of species of Phylum Cyanobacteria, such as Microcystis spp. resulting in the dominance of species Microcystis spp. (Prihantini et al., 2008).

It is commonly accepted that Cyanobacteria are often abundant in water samples or commonly called the Harmful Algal Blooms phenomenon. The main factor causing HAB in freshwater is eutrophication. Increased levels of nutrients in the waters coupled with the appropriate temperature and light, very slow water flow, and the presence of other supporting factors cause the blooming of Cyanobacteria in the waters (Kumar and Singh, 1979).

Most members of Cyanobacteria can produce toxins (cyanotoxins), consisting of biotoxins or toxins that cause death, acute diseases, chronic, or chronic poisoning in other organisms. Examples of cyanobacteria that have toxins are Anabaena flos-aquae, Aphanizomenon flos-aquae, and Oscillatoria spp. produce neurotoxins; Microcystis, Anabaena, Nostoc, and Oscillatoria produce hepatotoxins; and Umezakia natans, Aphanizomenon ovalisporum, and Cylindrospermopsis raciborskii which produce cytotoxins (Prihantini et al., 2008).

Furthermore, it is known that high or low N/P can lead to community growth or the dominance of certain types of phytoplankton (Haarcorryati, 2008). It is further noted that phytoplankton of the Cyanophyceae and Bacillariophyceae species can grow well at a low N/P ratio $(<10)$, while the Chlorophyceae type on the N/P ratio is slightly higher. This is consistent with the results of the study that the N/P ratio during the study in all treatments ranged from 4.4 to 5.6 (Dolman, 2012).

The growth phase of phytoplankton is influenced by the environmental conditions of its culture media, such as light, temperature, $\mathrm{pH}$, free $\mathrm{CO} 2$ content, as well as the availability of macro and micronutrients. The composition and abundance of phytoplankton will change at various levels in response to changes in physical, chemical, and biological environmental conditions (Reynolds, 1984). Supporting phytoplankton growth factors are very complex and interact with water physical-chemical factors, such as light intensity, dissolved oxygen, temperature stratification, and availability of nitrogen and phosphorus nutrients, while the biological aspect is the activity of predation by animals, natural mortality, and decomposition (Goldman and Horne, 1983).

The results of measurements of water temperature during the study are known to range $27-28.50^{\circ} \mathrm{C}$ (Table 2 ). It is known that the optimal temperature for phytoplankton growth is generally within the range of $20-240^{\circ} \mathrm{C}$. However, almost all types of phytoplankton are tolerant of temperatures ranging $16-360^{\circ} \mathrm{C}$. On the other hand, it is also known that the optimum temperature range for phytoplankton growth is $20-300^{\circ} \mathrm{C}$ (Effendie, 1979). Meanwhile, if the temperature is below $160^{\circ} \mathrm{C}$, then it can inhibit the speed of growth, while temperatures over $360^{\circ} \mathrm{C}$ can cause death in certain types of phytoplankton. Based on these criteria, it can be seen that the water temperature in the present study supported the life of phytoplankton. Also the results of temperature measurements were indicative of differences in temperature at each test and treatment. This can be caused by randomization so that the temperature at each treatment was different.

The results of $\mathrm{pH}$ measurements during the study ranged from 3.8 to 7.6 (Table 1). The low pH value (acid) could be due to the influence of several factors, including the decomposition of organic matter which may cause the water samples to become acidic. On the other hand, the $\mathrm{pH}$ range that supports phytoplankton growth is $7.5-8.5$. The $\mathrm{PH}$ variations can affect metabolism and phytoplankton growth through several things, including changing the balance of organic carbon, changing the availability of nutrients, and can affect cell physiology. The suitable $\mathrm{pH}$ range of the water for phytoplankton growth is 6.5-8.5. Based on these criteria, the $\mathrm{pH}$ conditions during the study felt less supportive of phytoplankton growth. On the other hand, to maintain $\mathrm{pH}$ stability, lime or dolomite can be added (Gunarto and Suwoyo, 2011). However, after the addition of dolomite lime, an increase in the $\mathrm{pH}$ did not occur and was still acidic.

In the current study, the $\mathrm{pH}$ values in the first and second weeks of treatment $\mathrm{A}$ showed the highest average of 6.1 and 4.6, respectively. This value was the highest, compared with treatments $\mathrm{B}$ and $\mathrm{C}$, since no addition of probiotic bacteria was added to treatment $\mathrm{A}$, so the decomposition process was not too high. Regarding treatments $\mathrm{B}$ and $\mathrm{C}$, the $\mathrm{pH}$ 
was inclined to be low and more acidic, since probiotic bacteria were added, so that in treatments $\mathrm{B}$ and $\mathrm{C}$, a decomposition process occurred by the bacteria which then affected the $\mathrm{pH}$ value.

Further trace, in the biofloc incubation process, an increase was made by adding two different commercial probiotics, namely commercial probiotics B and commercial probiotics $\mathrm{C}$. The role of microorganisms contained in commercial probiotic B was expected to accelerate the oxidation process of organic elements so that the content of organic elements and their quality can be improved (Irianto and Austin, 2002). Commercial Probiotics B was one type of biofertilizer. In the case of application, it can become active, and remodel organic material (Suwena, 2002). On the other hand, commercial probiotic $\mathrm{C}$ is known to contain active ingredients like microorganisms Lactobacillus spp., Nitrosomonas spp., Bacillus subtilis, and Bacillus spp.

Furthermore, the N/P ratio during the present study was below 10. According to Aiyushirota (2009), the distribution of plankton, such as Blue-Green Algae and dinoflagellates is determined by the proportion of the value of nitrogen to phosphorus.

In the eutrophic environment, the ratio of total ppm $\mathrm{N}$ is divided by total ppm $\mathrm{P}$ below $10 ; 10 \mathrm{~N} / \mathrm{P}$ ratio $<10$, and it was dominated by or red tide growth. Accordingly, it did not support the balance of water because of population domination due to Blue-Green Algae or red Tide.

Overall, the N/P ratio produced during the study was < 10: 1, making it suitable for the growth of cyanobacteria. Furthermore, it was revealed that the N/P ratio was highly influential on the dominance of the phytoplankton community, where it could be detrimental. This can be based on the regression value tested on the N/P ratio with the dominance frequency of Dinophyceae and Cyanophyceae ( $\mathrm{p}<0.001, \mathrm{R}: 0.848)$. In the current study, using commercial probiotics B and commercial probiotics $\mathrm{C}$ with a combination of $\mathrm{ZA}$ and dolomite fertilizers produced low N/P and lots of Cyanobacteria.

Further explored, it is known that the dominance of phytoplankton found in this study was Microcystis spp. Microcystis is algae/phytoplankton that is dominant in freshwater systems whether or not eutrophication occurs. Microcystis consumes the nitrogen needed for its growth in the form of nitrates (Jacoby et al., 2000). Nitrate is a form of a stable nitrogenous compound which is one of the important elements for the synthesis of plant proteins. Therefore, Microcystis is a bioindicator for water samples with high nitrate levels (Retnaningdyah et al., 2002).

It is also known that the growth of Microcystis is influenced by light intensity and irradiation time. Cyanobacteria are more commonly found in areas with high light intensity, especially in the middle of dry seasons. In addition, light plays a significant role in heating water meaning that the longer and greater the intensity of the light, the higher the water temperature. Temperature changes affect the suitability of waters as habitats because each aquatic organism has a range of minimum and maximum temperatures for its life (Closs et al., 2006).

\section{CONCLUSION}

It can be concluded that, first, the addition of different probiotics based on Bacillus spp., lactic acid, Lactobacillus spp., and Saccharomyces spp. in floc formation resulted in phytoplankton diversity was not significantly different regarding phytoplankton diversity. Moreover, the Nitrogen/Phosphorus (N/P) ratio which is a limiting factor for phytoplankton growth showed different results in each treatment, including treatments with or without probiotics.

\section{DECLARATIONS}

\section{Competing interests}

Authors declare no competing interests.

\section{Authors' contribution}

The authors have participated in this study equally.

\section{Ethical consideration}

Ethical issues (Including plagiarism, consent to publish, misconduct, data fabrication and/or falsification, double publication and/or submission, and redundancy) have been checked by the authors.

\section{REFERENCES}

Arias-Moscoso JL, Espinoza-Barrón LG, Miranda-Baeza A, Rivas-Vega ME, and Nieves-Soto M (2018). Effect of commercial probiotics addition in a biofloc shrimp farm during the nursery phase in zero water exchange. Aquaculture Reports, 11: 47-52. https://doi.org/10.1016/j.aqrep.2018.06.001

Avnimelech Y (1999). Carbon/nitrogen ratio as a control element in aquaculture systems. Aquaculture, 176(3): $227-235$. DOI: https://www.doi.org/10.1016/S0044-8486(99)00085-X 
Avnimelech Y, Verdegem MCJ, Perar K, and Kurup M (2008). Sustainable land-based aquaculture: rational utilization of water, land and feed resources. Mediterranean Aquaculture Journal, 1(1): 45-54. DOI: https://www.doi.org/10.21608/maj.2008.2663.

Closs G, Downes B, and Boulton A (2006). Freshwater ecology: A scientific introduction. Malden USA: Blackwell Publishing, 1: 1236. Available at: https://www.wiley.com/en-us/Freshwater+Ecology\%3A+A+Scientific+Introduction-p-9781444311136.

Crab R, Kochva M, Verstraete W, and Avnimelech Y (2009). Bio-flocs technology application in over-wintering of tilapia. Aquacultural Engineering, 40(3): 105-112. DOI: https://doi.org/10.1016/j.aquaeng.2008.12.004.

Dolman AM, Rucker J, Pick FR, Fastner J, Rohrlack T, Mischke U, and Wiedner C (2012). Cyanobacteria and Cyanotoxins: The Influence of Nitrogen versus Phosphorus. PLoS One,7(6): 1-13. DOI: https://doi.org/10.1371/journal.pone.0038757

Effendi H (2003). Telaah kualitas air, bagi pengelolaan sumber daya dan lingkungan perairan. Kanisius, 4(1): 1-64. Available at: http://repository.ipb.ac.id/handle/123456789/79927

Effendie MI (1979). Metode biologi perikanan. Penerbit Yayasan Dewi Sri. Bogor, 1: 1-112. Available at: http://opac.lib.ugm.ac.id/index.php?mod=book_detail\&sub=BookDetail\&act=view\&typ=htmlext\&buku_id=638808\&obyek_id= $\underline{1}$

Goldman CR, and Horne AJ (1983). Limnology. McGraw-Hill. Book Co., New York. 1: p. $464 . \quad$ DOI: https://doi.org/10.4319/lo.1984.29.2.0447b

Gunarto G, and Suwoyo HS (2011). Produksi bioflok dan nilai nutrisinya dalam skala laboratorium. in Prosiding Forum Inovasi Teknologi Akuakultur, Pp. 1009-1017. Available at: http://ejournal-balitbang.kkp.go.id/index.php/fita/article/view/4985

Haarcorryati A (2008). Hubungan rasio N/P dengan kecenderungan dominasi komunitas mikroalga pada waduk-waduk di DAS citarum. Buletin Keairan, 1(1): 1-8. Available at: http://lib.ui.ac.id/file?file=pdf/metadata-121038.pdf

Irianto A, and Austin B (2002). Probiotics in aquaculture. Journal of Fish Diseases, 25(11): 633-642. DOI: https://doi.org/10.1046/j.1365-2761.2002.00422.x

Jacoby JM, Collier DC, Welch EB, Hardy FJ, and Crayton M (2000). Environmental factors associated with a toxic bloom of microcystis aeruginosa, Canadian Journal of Fisheries and Aquatic Sciences, 57(1): 231-240. DOI: https://www.doi.org/10.1139/f99-234

Kumar HD, and Singh HN (1979). A textbook on algae (Macmillan International College Edition). Macmillan International Higher Education, 2(1): 1-231. DOI: https://www.doi.org/10.1007/978-1-349-16144-7

Mukti AT, Arief M, and Satyantini WH (2003). Dasar-Dasar akuakultur. Program Studi Budidaya Perairan. Fakultas Kedokteran Hewan. Universitas Airlangga. Surabaya hal, pp. 81-98. Available at: https://scholar.google.com/scholar?hl=en\&as_sdt=0,5\&cluster=16330410496134972896

Nontji A (2007). Laut Nusantara. edisi revisi cetakan kelima. Jakarta: Djambatan. p. 367. Available at: https://books.google.co.id/books/about/Laut_Nusantara.html?id=VWVQNQAACAAJ\&hl=id

Nybakken JW, and Eidman HM (1992). Biologi laut: Suatu Pendekatan Ekologis. Terjemahan. Gramedia Jakarta, p. 257. Available at: http://lib.ui.ac.id/detail?id=140750

Ogello EO, Musa SM, Aura CM, Abwao JO, and Munguti JM (2014). An appraisal of the feasibility of tilapia production in ponds using biofloc technology: A review. International Journal of Aquatic Science, 5(1): 21-39. Available at: http://www.journalaquaticscience.com/article_73489_f88d6284e29c36aac48bdac5b63451e5.pdf

Odum EP (1953). Fundamentals of ecology, third, edition, Philadephia: WB Saunders, 38(4): $314 . \quad$ DOI: https://doi.org/10.1002/sce.3730380426

Prihantini NB, Wardhana W, Hendrayanti D, Widyawan A, Ariyani Y, and Rianto R (2008). Biodiversitas cyanobacteria dari beberapa situ/danau di kawasan Jakarta-Depok-Bogor, Indonesia. Makara Journal of Science, 12(1): 44-54. DOI: https://www.doi.org/10.7454/mss.v12i1.309.

Retnaningdyah C, Prayitno Y, Rosyitawati, Dewi MYC, and Hartini AN (2002). Potensi mikroalga sebagai bioindikator tingkat pencemaran bahan organik di perairan waduk. National Seminar on Research and Studies Research Grant conducted by Ministry of National Education, Directorate General of Higher Education, TPSDP, Jakarta December, Pp. 27-28. Available at: https://lppm.ub.ac.id/wp-content/uploads/2012/03/catur-retnoning.pdf

Reynolds CS (1984). The ecology of freshwater phytoplankton. Cambridge University Press. p. $384 . \quad$ DOI: https://doi.org/10.1017/CBO9780511542145.002

Suwena M (2002). Peningkatan produktivitas lahan dalam sistem pertanian akrab lingkungan. Makalah Pengantar Filsafah Sains. Bogor, p. 53. Available at: https://www.rudyct.com/PPS702-ipb/05123/made suwena.htm

Wyk PV, and Avnimelech Y (2007). Management of nitrogen cycling and microbial populations in biofloc-based aquaculture systems. Presentation in World Aquaculture, pp. 1-24. Available at: https://www.aesweb.org/presentations/biofloc/SanAntonio2007/Management\%20of\%20nitrogen\%20cycling \%20and\%20microbi al\%20populations $\% 20$ in $\% 20$ bioflocbased $\% 20$ aquaculture $\% 20$ systems.pdf 